DOI 10.4467/2543733XSSB.17.006.7252

JÓZEF ŁAPTOS

Uniwersytet Pedagogiczny im. KEN w Krakowie

\title{
ZAKRES I FORMY WSPÓLPRACY POLITYKÓW ŚRODKOWOEUROPEJSKICH NA UCHODŹSTWIE W CZASIE II WOJNY ŚWIATOWEJ ${ }^{1}$
}

Słowa kluczowe: federacja środkowoeuropejska, polityka rządów emigracyjnych, plan Sikorskiego, sprawa polska w czasie II wojny

W czasie II wojny światowej wszystkie państwa w Europie okupowane przez Niemcy miały swe rządy na emigracji i korzystały z precedensu w prawie międzynarodowym, jaki stanowiło uznanie rządu belgijskiego na uchodźstwie w czasie I wojnie światowej. Odmienne jednak były cele, jakie stawiały sobie rządy państw zachodnich, a rządy reprezentujące Europę Środkową. O ile bowiem dla Holendrów czy Belgów zamierzeniem był powrót do sytuacji sprzed wojny, o tyle dla uchodźców środkowoeuropejskich powrót do status quo ante w polityce ich państw był nie do pomyślenia ani tym bardziej do występowania z nim wobec sojuszników. Przeszkodę stanowił fakt, że przed wojną w tych krajach mieliśmy do czynienia z rządami autokratycznymi, z jednym chwalebnym wyjątkiem, jakim była Czechosłowacja. Kolejną przesłanką była świadomość własnej słabości wobec potężnych sąsiadów. Rozwiązaniem racjonalnym stawała się federacja. Po pierwsze, kto mówi federacja, ten mówi demokracja, po drugie jedynie federacja stanowiła szansę na wzmocnienie bezpieczeństwa całego obszaru. Tak więc z głębokim przekonaniem stawiano na ścisłą współpracę państw całego obszaru środkowoeuropejskiego, w której widziano jedyną szansę na uzyskanie podmiotowości na arenie międzynarodowej.

Przedstawiciele małych państw leżących między Niemcami a Rosją byli głęboko przekonani o konieczności przeprowadzenia zmian w polityce wewnętrznej i zagranicznej swoich krajów. Dla nich celem wojny było nie tylko pokonanie Niemiec, ale także uwolnienie się na przyszłość od roli buforu (l’Etat tampon), monety przetargowej (la monnaie d'échange), strefy wpływów (zone d'influence), kordonu sanitarnego - całej metaforyki, która przeniesiona na grunt rzeczywistości była od wieków przyczyną nieszczęść tego regionu. Cześć polityków nie mogła się przy tym pozbyć poczucia ciążącej

${ }^{1}$ Artykuł przygotowany w ramach grantu NCN nr 2013/08/M/HS3/00395 
na nich odpowiedzialności za krótkowzroczność polityki prowadzonej w okresie międzywojennym.

Stylizowana na wiele sposobów owa prise de conscience najdobitniej chyba została wyrażona piórem Josefa Henca:

Było tragicznym błędem powojennej klasy politycznej w Środkowej Europie uciekanie się, przy byle zatargu, do zbiorowej odpowiedzialności zamiast dążenia do jednoczenia sił w celu zapobieżenia, pozornie odległym, ale widocznym i groźnym niebezpieczeństwom. Ruiny Entent: Bałtyckiej, Małej czy Bałkańskiej są milczącymi świadkami dyplomatycznego szaleństwa. Cóż bardziej żałosnego niż obraz Litwinów odzyskujących Wilno, ale gubiących Litwę, Polaków zdobywających Cieszyn, ale tracących Polskę, Węgrów uzyskujących Siedmiogród, ale zaprzedających państwo czy Bułgarów otrzymujących Dobrudżę w zamian za utratę Bułgarii².

Wiary i optymizmu co do możliwości wyjścia z zaściankowych sporów granicznych przysłaniających wyższe cele nie brakowało. Jan Papanek, dyplomata czeski, którego wojna zastała w Nowym Jorku, na wieść o pierwszej deklaracji czechosłowacko-polskiej w sprawie konfederacji, ogłoszonej 11 listopada 1940 r., pisał:

Narody czeski i polski zrozumiały lekcję historii. Teraz ich rządy w Londynie podały sobie ręce i zgodziły się przede wszystkim na to, że nowa współpraca oparta będzie jedynie na wspólnych interesach, że spory z przeszłości zostaną zapomniane. Kroki (démarches) poczynione przez obydwa rządy w Londynie są zgodne z postawą i odczuciem społeczeństw ich krajów³

Wtórował mu niczym echo były polski dyplomata, Anatol Mühlstein:

W rzeczywistości nigdy nie było prawdziwego konfliktu między tymi dwoma narodami. Były jedynie spory, celowo podsycane przez polityków, które u obserwatorów z zewnątrz sprawiały wrażenie żywotnego konfliktu

Vojta Beneš, brat czechosłowackiego prezydenta, podkreślał:

Wiemy, że nowa Europa musi stać się domem współpracy, wzajemnej tolerancji, zrozumienia i pomocy ${ }^{5}$.

By nie tworzyć antologii interesujących skądinąd wystąpień, poprzestańmy na przypomnieniu głównych wniosków, do jakich dochodzili ich autorzy w ocenie polityki dwudziestolecia. Należały do nich niewątpliwie: konieczność odejścia od centralizmu na rzecz federalizmu, podniesienie znaczenia władz lokalnych i samorządów, ustanowienie ponadnarodowego autorytetu dla obrony pokoju, wzmocnienie instytucji demokratycznych, wprowadzenie gwarancji przeciw totalitarnej władzy. Wydawało się, że dylemat, przed jakim stają Europa i świat, to wybór między anarchią a rozwiązaniem federacyjnym.

2 J. Hen c, From Polish-Czechoslovak Collaboration to Eastern Organization, New Europe, czerwiec 1941, s. 175.

3 J. P a pa n e k, Significance of the Czechoslovak-Polish declaration, New Europe, grudzień 1940, s. 10.

${ }^{4}$ A. Muhlstein, The United States of Central Europe, New Europe, luty 1941, s. 60. Ten obszerny artykuł publikowany w trzech kolejnych numerach ukazał się następnie w postaci odrębnej broszury (Nowy York 1942) oraz jako artykuł we Free World (październik 1942) pt. Plans for the Future.

5 V. B e n e š, The Mission of Small Nations, Chicago 1941 s. 96. 
Spośród licznych projektów dotyczących przekształcenia Europy Środkowowschodniej największego rozgłosu nabrała inicjatywa federacji środkowoeuropejskiej, propagowana przez premiera polskiego rządu Władysława Sikorskiego. Zagadnienie to w historiografii polskiej i poniekąd także czeskiej jest, nie wiadomo dlaczego, redukowane jedynie do negocjacji dyplomatycznych w sprawie konfederacji polsko-czechosłowackiej. Warto zatem, przy okazji niniejszych rozważań, przywrócić należne jej miejsce w historii integracji europejskiej i zająć się nieco szerzej tą wizją, która wywrzeć miała niemały wpływ na postawę całej emigracji i przyczyniła się generalnie do ożywienia myśli federacyjnej w okresie wojny.

Projekt nadania Europie Środkowej nowego kształtu wysunięty został dość wcześnie. Generał Władysław Sikorski wzmiankował go już w swej pierwszej deklaracji rządowej z 16 listopada 1939 r., zaś miesiąc później - 18 grudnia - w kolejnym wystąpieniu w Angers na temat celów polityki zagranicznej rządu polskiego na emigracji stwierdził m.in.:

W ramach nowej organizacji politycznej Europy Środkowowschodniej, jedną z głównych podstaw stać się musi solidarny zespół państw słowiańskich. Nowa organizacja w tej części Europy powinna stworzyć pomiędzy Bałtykiem, Morzem Czarnym a Adriatykiem zwarte i zgodne współdziałanie państw, odpierać napór Niemiec na Wschód i oddzielić Niemcy od Rosjíb.

Wiarygodności tym słowom dodawały rozmowy na temat zacieśnienia więzów między dwoma krajami, prowadzone z Edwardem Benešem, stojącym na czele Czechosłowackiego Komitetu Narodowego i z Milanem Hodžą, kierującym Narodowym Komitetem Słowackim.

Sikorski, o czym się zapomina, nie poprzestawał jednak na negocjacjach dwustronnych. Równolegle z démarches w sprawie konfederacji polsko-czechosłowackiej, korzystając z autorytetu, jakim się cieszył w londyńskiej „,małej Europie”, inicjował regularne spotkania na szczeblu ministrów spraw zagranicznych Belgii, Holandii, Luksemburga i Norwegii, a od połowy 1941 r. także Jugosławii i Grecji. Ich przedmiotem były wszelkie problemy, przed jakimi stanęłyby małe państwa w czasie odbudowywania powojennej Europy, wobec czego zmierzano do tworzenia zorganizowanej grupy nacisku. Efekty tej współpracy nie były małe i wykraczały daleko poza środowisko londyńskie. O jednym z nich Sikorski wspomniał w swej relacji z pierwszej podróży do Stanów Zjednoczonych:

Podczas tej wizyty zgrupowali się razem z Polakami, Czechosłowacy, Jugosłowianie i Grecy, a nawet Holendrzy i Belgowie. Odtąd emigracje tych krajów powinny występować solidarnie w sprawach polityki światowej na kontynencie amerykańskim ${ }^{7}$

Słowom polskiego premiera dodaje głębi lektura „New Europe”, czasopisma stanowiącego interesującą trybunę prointegracyjną emigracji środkowoeuropejskiej na terenie Stanów Zjednoczonych ${ }^{8}$. Należy także podkreślić, iż spotkania londyńskie inicjowane

${ }^{6}$ Cyt. za: T. Kisielewski, Federacja środkowoeuropejska. Pertraktacje polsko-czechosłowackie 1939-1943, Ludowa Spółdzielnia Wydawnicza, Warszawa 1991 s. 37; Por. P.S. Wan dy c z, Czechoslovak-Polish Confederation and the Great Powers 1940-1943, Indiana University Publications, 1956, s. 34.

${ }^{7}$ Oświadczenie W. Sikorskiego na posiedzeniu Rady Narodowej RP 4.06.1941, [w:] S. S t a n is ł a w s k a, Sprawa polska w czasie drugiej wojny światowej. Zbiór dokumentów, PWN, Warszawa 1965, s. 206.

${ }^{8}$ I. D rąg-K orga, Polska Walczy! Działalność propagandowa rzadu RP na uchodźstwie wobec spoteczeństwa amerykańskiego 1939-1945, Instytut Józefa Piłsudskiego w Warszawie, Bełchatów 2011, s. 63-71. 
przez Sikorskiego, przyczyniły się do wypracowania koncepcji układu grecko-jugosłowiańskiego, mającego stanowić zalążek drugiego ośrodka związków regionalnych na obszarze między Niemcami a Rosją . W tej ostatniej kwestii, jak sugerują dane wywiadu amerykańskiego, pewną rolę odegrała inspiracja, a może nawet presja rządu brytyjskiego $^{10}$. Rezultatem podjętych zabiegów stała się deklaracja grecko-jugosłowiańska w sprawie ekonomicznej i społecznej współpracy krajów tego obszaru w przyszłości, opublikowana 12 czerwca 1941 r., a więc niemal natychmiast po zainstalowaniu się nowych rządów na emigracji ${ }^{11}$.

Kolejną płaszczyzną do zamanifestowania wspólnych dążeń przez przedstawicieli okupowanej Europy Środkowowschodniej stała się zwołana do Nowego Jorku w listopadzie 1941 r. sesja Międzynarodowej Organizacji Pracy. W nawiązaniu do przyjętego wówczas apelu w sprawie organizacji powojennego świata, delegaci wspomnianych wyżej krajów wystąpili z koncepcją bliższej współpracy, uwzględniającej specyfikę regionu. Punkt 6 deklaracji głosił m.in.:

Mamy nadzieję, że po zakończeniu wojny, w którą zostaliśmy uwikłani wbrew własnej woli, ponad sto milionów mieszkańców Europy Środkowej i Bałkanów zostanie wyzwolonych ze stanu nędzy. Wierzymy, że dzięki odbudowie i rozbudowie ich przemysłu i rolnictwa oraz marynarki handlowej zostanie im zapewnione stałe zatrudnienia i że te narody zostaną włączone, bez żadnych restrykcji, do szerszego projektu międzynarodowej wymiany dóbr i usług ${ }^{12}$.

Szeroki odzew, jaki deklaracja wywołała w środowiskach emigracyjnych ${ }^{13}$, skłonił następnie jej sygnatariuszy do utworzenia naukowej placówki, która pod nazwą Rada Planowania dla Europy Środkowowschodniej (Central Europe Planning Board) funkcjonowała do 1944 r. i opublikowała szereg interesujących analiz ekonomicznych. Kolejną sferę współpracy zaproponowali przedstawiciele partii chłopskich środkowej Europy, zgrupowani w odrodzonej na emigracji „Zielonej Międzynarodówce”, którzy akcentowali potrzebę regulacji rynków i współpracy w tej dziedzinie z Wielką Brytanią, Stanami Zjednoczonymi i ZSRR ${ }^{14}$.

$\mathrm{Na}$ sugestie idące $\mathrm{z}$ Londynu zareagowali również emigranci z krajów satelickich III Rzeszy. W otoczeniu hrabiego Tibora Eckhardta, wysłanego w 1941 r. przez Horthyego na Zachód w celu nawiązania kontaktów z Aliantami i węgierską opozycją, powstał

9 Potwierdza to P.-H. Spaak, w swych wspomnieniach (Combats inachevés, t. I, Paris 1968, s. 155), dodając, że współautorem tych koncepcji był J. Retinger.

${ }^{10}$ National Archives, Waszyngton (dalej: NA), RG 226 OSS INT, GR-337, Raport wywiadu amerykańskiego na temat polityki E.J. Tsouderosa z 21.06.1942.

${ }_{11}$ P. H. Spaak, op. cit., s. 91; Zob. także M. Herzog, Yougoslavia and Federalism, New Europe, nr 12, październik 1941, s. 323.

12 Tekst deklaracji: F. Gros s, Crossroads of two Continents. A Democratic Federation of East-Central Europe, Columbia University Press, New York 1945, dok. X, s. 107-109. Wśród jej sygnatariuszy znaleźli się z delegacji czechosłowackiej: J. Masaryk, J. Nečas, R. Moravec, J. Kosina, greckiej: A. Dimitratos, G. Logothetis, D. Papas; polskiej: J. Stańczyk, A. Falter, F. Gross; jugosłowiańskiej: S N. Kosanović, B. Bonats, C. Milos, Zob. także: F. Gross, Planning and Federation at the International Labor Organization Conference, New Europe, nr 1, grudzień 1940 s. 11.

${ }_{13}$ Zob. m.in. J. Masaryk, A Lasting Brotherhood of Free Peoples, New Europe, t. II, grudzień 1941; S. N. K o s a n o i c h, Common Aspirations of the Nations of Eastern Europe...

14 N.N. P e a s a t, Charter Drafted for Liberalized Europe, The Christian Science Monitor, 21 VII 1942. 
wówczas projekt integracji Europy naddunajskiej, nazwany później „planem Eckhardta-Pelenyiego"".

Pewien problem stwarza natomiast kształt proponowanej federacji. Leon Mitkiewicz, bliski współpracownik Sikorskiego, przytaczając jedną z jego wypowiedzi, wymienił Polskę, Czechosłowację, Litwę i Jugosławię jako tworzące ją państwa ${ }^{16}$. Z kolei Retinger twierdził, że Sikorski był zwolennikiem związku grupującego poza Polską i Czechosłowacją także państwa bałtyckie, Węgry i ewentualnie Austrię oraz Rumunię ${ }^{17}$. Podobne informacje w sprawie „Planu Sikorskiego” posiadali członkowie Komitetu Doradczego Departamentu Stanu:

Na temat Planu można było uzyskać jedynie kilka szczegółów. Państwa mające wchodzić do proponowanego związku to kraje bałtyckie, Polska, Czechosłowacja, Węgry, Rumunia i Jugosławia. Plan zakłada całkowitą federację pod względem gospodarczym. Przyniosłaby ona polityczne korzyści Polsce, która w tej ponadnarodowej strukturze posiadałaby wyraźną przewagę, zwłaszcza w odniesieniu do państw bałtyckich. Jednakże proponując szeroką federację, ta dominacja uległaby samoograniczeniu, co znaczy, że jej wyhamowanie mieściło się w założeniach planu ${ }^{18}$.

Początek 1942 r. londyńska „Mała Europa” witała z optymizmem i nadzieją. Dobiegały właśnie końca przygotowania do podpisania negocjowanego od dawna układu w sprawie konfederacji polsko-czechosłowackiej. Równocześnie przedstawiciele Grecji i Jugosławii dokonywali ostatnich poprawek redakcyjnych podobnej umowy i jako pierwsi podpisali 15 stycznia 1942 r. „Porozumienie między Królestwem Grecji i Królestwem Jugosławii w sprawie ustanowienia Unii Bałkańskiej”. Sygnatariuszami tego aktu byli ze strony greckiej Emmanouil Tsouderos, premier i zarazem minister spraw zagranicznych ${ }^{19}$ oraz podsekretarz stanu greckiego MSZ, a ze strony jugosłowiańskiej prof. Slobodan Jovanovič, premier i minister spraw wewnętrznych oraz Momčilo Nincić, minister spraw zagranicznych.

Zaskoczenie opinii publicznej było duże, gdyż na temat współpracy tych rządów niewiele było wcześniej wiadomo, m.in. z racji stosunkowo niedawnego ich działania na uchodźstwie. Lektura deklaracji budziła zatem zrozumiałe zainteresowanie i zdawała się utwierdzać w przekonaniu, że lekcja historii została w pełni przyswojona także na Bałkanach. Preambuła porozumienia głosiła wszak, że nowy związek rodzi się z

(...) doświadczenia wynikającego z przeszłości, a szczególnie z niedawnych wydarzeń, które wskazują, że brak bliskiego porozumienia pomiędzy narodami bałkańskimi doprowadził do

15 P. P a s to r, Hungarian Emigrés in Wartime Britain, [w:] J. Mor is o n, Eastern Europe and the West. Selected papers from Forth World Congress for Soviet and East European Studies, New York 1992, s. 81-97 oraz I. R o m s ic s (ed.), Wartime American Plans for a New Hungary, Documents from the U.S. Department of State, 1942-1944, Columbia University Press, New York 1992, s. 20-21.

${ }^{16}$ L. Mitk i e w i c z, Z generałem Sikorskim na obczyźnie, Paryż 1968, s. 143.

17 Ibidem.

${ }^{18}$ NA, Notter Files, box 57, P doc. 46. Zob. także: J. L a p to s, M. M i s z t a l (red.), American Debates on Central European Union, 1942-1944. Documents of the American State Department, Presses Internationales Universitaires. Peter Lang (seria Euroclio), Bruxelles-Berlin-Frankfurt-New York-Oxford-Wien 2002, dok. 1, przypis 174 .

19 E. J. Tsouderos, prawnik z wykształcenia, sprawował wiele funkcji politycznych przed wojną i był bliskim współpracownikiem E. Wenizelosa. W rządzie utworzonym na emigracji 20.04.1941 r. pełnił początkowo obowiązki ministra spraw zagranicznych i ministra finansów, a następnie premiera. 
wykorzystania ich przez agresywne mocarstwa drogą politycznej i militarnej penetracji, a następnie dominacji półwyspu ${ }^{20}$.

Unia Bałkańska, która miała powstać w wyniku tego porozumienia, jak można wnosić z kompetencji jej poszczególnych organów, byłaby konfederacją. Organ Polityczny składający się z ministrów spraw zagranicznych, obradujący w ściśle ustalonych terminach, miałby koordynować zagraniczną politykę wszystkich państw w celu prezentowania jednolitej wykładni na forum międzynarodowym. Czuwałby ponadto nad działalnością wielu komisji przygotowujących projekty arbitrażu, współpracy intelektualnej, oddziaływania na opinię publiczną etc. Organ Ekonomiczny i Finansowy, w skład którego wchodzić miało po dwóch szefów resortów zajmujących się kwestiami gospodarczymi w poszczególnych państwach Związku, uzyskał szerokie uprawnienia w dziedzinie handlu zagranicznego, taryf celnych, opracowywania planów gospodarczych i ich korelacji z planami cząstkowymi. Miał też szerokie kompetencje w zakresie powoływania nowych komisji w celu wypracowania unii monetarnej, usprawnienia łączności i komunikacji między krajami związkowymi oraz rozwoju turystyki ${ }^{21}$.

Twórcy układu dużą wagę przywiązywali do zagadnień obronności, o czym świadczyło ustanowienie Stałego Organu Wojskowego z udziałem szefów państw lub ich zastępców, współpracujących ściśle ze Wspólnym Sztabem Generalnym, skupiającym, oczywiście, przedstawicieli poszczególnych sztabów narodowych. Zadaniem sił zbrojnych Unii, nad którymi miałby pieczę, była obrona „,europejskich granic państw Unii”. Natomiast Stałe Biuro, przewidziane w porozumieniu, miało pełnić rolę Sekretariatu.

Podpisana w Londynie umowa wchodziłaby w życie po ratyfikacji przez narodowe parlamenty natychmiast po zakończeniu wojny ${ }^{22}$.

Osiem dni później, 23 stycznia 1942 r. doszło do podpisania wspomnianej deklaracji czechosłowacko-polskiej, która w opinii Małej Europy londyńskiej stanowiła potwierdzenie woli tworzenia federacji środkowoeuropejskiej. Sygnatariusze deklaracji, określanej w polskiej literaturze jako „układ o zasadach przyszłej konfederacji”"23, zadbali zresztą o to, by wrażenie takie utrwalić. W komunikacie ogłoszonym tego samego dnia obydwa rządy wyrażały przekonanie, że

konfederacja państw Europy Środkowej będzie współpracować z Unią Bałkańską przewidzianą przez rządy Grecji i Jugosławii i że jedynie współpraca między tymi dwiema organizacjami regionalnymi może zapewnić bezpieczeństwo i przyczynić się do wzrostu dobrobytu szerokiego obszaru, położonego między Bałtykiem a Morzem Egejskim²4.

Ta wspaniała perspektywa współdziałania, przyjmowana z wielkim optymizmem przez środowiska emigracyjne, nie znajdowała, niestety, potwierdzenia w treści dokumentu, który zasadniczą kooperację zapowiadał w dość nikłym stopniu. Polsko-czechosłowacka deklara-

\footnotetext{
${ }^{20}$ F. Gros s, op. cit., dok. IX, s. 104.

${ }^{21}$ Por. E. Zn a m i e ro w s k a-R a k k, Projekty unifikacji państw bałkańskich w latach II wojny światowej, Dzieje Najnowsze, 2001/3, s. 88-89.

${ }^{22}$ Tekst: F. Gros s, op. cit., dok. IX, s. 104-106.

${ }^{23}$ T. Kis ielewski, op. cit., s. 174. Tekst projektu zob.: S. Kirkor, Rola Benesza w sprawie polskiej w 1944 roku, Zeszyty Historyczne, nr 26/1973, s. 54-56.

${ }^{24}$ Cyt. za:. T. Kis i elew ski, op. cit., s. 175.
} 
cja pod tym względem sformułowana była ostrożniej niż południowosłowiańska. Obydwa rządy wyrażały pragnienie, aby konfederacja objęła także ,inne państwa europejskie tego obszaru, z którymi związane są żywotne interesy Polski jak i Czechosłowacji”, ale nie wymieniała ich z nazwy ani też nie precyzowała czasu, w jakim to miałoby nastąpić. Cel współdziałania zakreślono skromnie: zapewnienie wspólnej polityki w dziedzinie spraw zagranicznych, obrony, spraw socjalnych, transportu, poczty i telegrafu. Przyszła konfederacja miała posiadać wspólny sztab generalny, a w razie wojny także wspólne dowództwo. W kolejnych sześciu punktach strony zapowiadały koordynację strategii w kwestiach dotyczących handlu zagranicznego, stawek celnych, polityki monetarnej, komunikacji oraz szkolnictwa i kultury. Punkt dwunasty wyliczał wolności i prawa obywatelskie, jakie powinny być zapewnione przez konstytucje poszczególnych państw. Końcowe postanowienia akcentowały wolę i potrzebę „stworzenia wspólnych organów konfederacji”25.

Obydwa porozumienia nie zapowiadały w sumie jakichś rewolucyjnych zmian. W jednym i w drugim przypadku struktura i niepodległość państw wchodzących w nowy związek pozostawała praktycznie nienaruszona. Organy federalne w zasadzie mieściły się w formule rozbudowanego stałego sekretariatu i spotkań międzyrządowych ${ }^{26}$. Można się było też zastanawiać, jak to czyniła znana Czytelnikowi Komisja Doradcza Departamentu Stanu ${ }^{27}$, czy deklaracja polsko-czechosłowacka wnosiła cokolwiek do poprzedniego dokumentu z 1940 r., czy układ grecko-jugosłowiański wychodził poza ustalenia Ententy Bałkańskiej z 1934 r. i czy obydwie inicjatywy sięgały sedna problemu?

Głębsza analiza treści obydwu dokumentów, jak skłonni jesteśmy twierdzić, nie jest konieczna, a może nawet niewskazana dla zrozumienia wagi wydarzenia. Rzecz bowiem w tym, że członkowie londyńskiej diaspory sami nie dokonywali egzegezy owych deklaracji. Dla nich ważniejszy był duch układów. Szukano go (i znajdowano) w dojrzałości politycznej środkowoeuropejskich polityków, w ich woli ograniczenia własnej suwerenności w imię bezpieczeństwa i pokoju ${ }^{28}$. Układy działały na wyobraźnię, inspirowały do dalszej debaty nad koniecznością nowej organizacji powojennej Europy. Mogły też mieć ogromną wagę, wskazując (wielkim mocarstwom), jak twierdził grecki premier, na ,jeden z fundamentalnych filarów przyszłego pokoju"29.

Emblematycznym przejawem wpływu aury, jaką te poczynania tworzyły, okazała się reakcja Ferdinanda de Van Langenhove, sekretarza generalnego belgijskiego ministerstwa spraw zagranicznych. Pozostając pod ogromnym wrażeniem obu deklaracji, skierował on do swego ministra, Paula-Henri Spaaka memoriał, w którym nie tylko bardzo wysoko oceniał ostatnie porozumienia, ale czerpał z nich inspirację do zaproponowania kolejnych kroków. Był przekonany, że deklaracje stanowiły „,przejście od rozważań wstępnych do studiów definitywnych” i kryły w sobie ,,zarodek konstruktywnego planu”30. Pełen uzna-

${ }^{25}$ Ibidem, s. 268-269.

${ }^{26}$ V. M. D e a n, European Agreements for post-war Reconstruction, Foreign Policy Report, 15.03.1942, Foreign Policy Association, New York 1942, s. 4-5 ocenia propozycję grecką jako bardziej klarowną (agreement is the most explicit).

${ }^{27}$ NA RG 59, Notter Files, t. 83, R.-6, 1 T-356, 27.07.1943, The Greek-Yugoslav Project for Balkan Union.

${ }_{28}$ T. Ko ma rn i ck i, Próba stworzenia związku polsko-czechosłowackiego $w$ okresie II wojny światowej, Sprawy Międzynarodowe, Londyn 1947, nr 2-3, s. 64.

29 NA, RG 26, OSS INT-GR-11, raport z 5.05.1943.

${ }^{30}$ Archives du Ministère des Affaires Etrangères (Bruksela), v. 11 775, Londyn 31.01.1942, Memorandum F. de Van Langenhove, Les fédérations régionales. 
nia dla dojrzałości polityków środkowoeuropejskich sugerował swemu ministrowi, by nie pozostawać w tyle i podjąć działania zmierzające do przygotowania podobnego projektu dla Europy Zachodniej oraz

powołania, w sposób mniej lub bardziej spektakularny, komisji studiów, której minimalnym zadaniem byłoby wyrażenie woli ustanowienia dobrego sąsiedztwa ${ }^{31}$.

Spaak nie zareagował początkowo na sugestie sekretarza generalnego MSZ, ale uczynił to minister finansów w jego rządzie, Paul Van Zeeland. Idąc tokiem rozumowania Langenhovego, zaproponował utworzenie „Unii Ekonomicznej”, obejmującej Wielką Brytanię, Francję, Belgię, Luksemburg, Holandię, Szwajcarię i kraje skandynawskie. Rozważał także kwestię współpracy Unii ze Stanami Zjednoczonymi, ale zdecydowanie odrzucał udział w niej Niemiec. Van Zeeland zasadzał swą koncepcję na reformach handlowych i finansowych, mających zmniejszyć znaczenie waluty jako narzędzia interesów narodowych. Przewidywał także liberalizację wymiany ekonomicznej oraz odejście od parytetu w złocie. Przyjęcie tych rozwiązań powinno w krótkim czasie zaowocować podniesieniem poziomu gospodarczego krajów członkowskich, a w przyszłości zapobiec dominacji Niemiec w Europie ${ }^{32}$.

„Federacja dunajska” i ,federacja Słowian północnych” jawiły się jako bardzo pożądane także hr. Henri de Grubenowi, radcy ambasady belgijskiej w Waszyngtonie, zwłaszcza gdyby udało się je powiązać z federalizacją niektórych wielkich państw, od Niemiec poczynając ${ }^{33}$. Inny przedstawiciel Belgii, przywódca katolickich Flamandów, witał z radością obydwa układy, dowodząc, że Belgia i Holandia powinny także ,wykazać dużo dobrej woli i mądrości” i pójść śladem państw środkowoeuropejskich ${ }^{34}$.

Mniej entuzjazmu okazywali politycy holenderscy, którzy poprzestawali na powrocie do status quo ante. Premier rządu holenderskiego P. S. Gebrandy, zapewne w nadziei utrzymania kolonii, stwierdził w wywiadzie dla prasy, że dla jego kraju, mającego rozległe kontakty handlowe i interesy poza Europą, nie jest celem czysto europejskie zgrupowanie narodów. Przy okazji powtórzył tezę, że Holandia ma więcej wspólnego ze Stanami Zjednoczonymi i Wielką Brytanią niż z innymi krajami europejskimi ${ }^{35}$.

Im bardziej na północ, tym chłodniejsze były reakcje na temat zawartej w omawianych układach sugestii federalizacji Europy. Związki regionalne nie ekscytowały polityków skandynawskich. Poselstwo amerykańskie, śledzące miejscową prasę, informowało Departament Stanu, że nawet proponowana wcześniej Unia Północna wydawała się nie do pomyślenia z obawy przed dalszymi napięciami w stosunkach fińsko-radzieckich i ze względu na przekonanie, że Norwegia, jak wnosić można było z jej doświadczenia historycznego, nigdy nie zgodzi się ustąpić ze swych praw suwerennych ${ }^{36}$.

Interesujące były natomiast reakcje przedstawicieli opozycji z krajów faszystowskich i pozostających w orbicie III Rzeszy. Carlo Sforza, były dyplomata włoski, znany

31 Ibidem.

32 The Christian Science Monitor, 11.07 i 10.10 .1942$.

33 Documents Diplomatiques Belges 1941-1960 (dalej DDB), t. I., J. Gotovitch (red.), Le gouvernement belge de Londres 1941-1944, Bruxelles 1998 ; Notatka barona de Grubena z marca 1942.

${ }_{34}$ F. van Cauw e la e rt, Dangers of European Federation, Belgium, nr 2, 2.04.1942, s. 47.

35 Sunday Times, 18.01.1942.

36 NA Notter Files, t. 84, raporty prasowe z 16, 20, 21 i 22 lipca 1942 
antyfaszysta, który znalazł schronienie na terenie Stanów Zjednoczonych, odpowiedział pozytywnie już na samą zapowiedź utworzenia konfederacji polsko-czechosłowackiej, jako początku konsolidacji Europy Środkowej w oparciu o przesłanki cywilizacyjne:

W konfrontacji z nazistowskim poganizmem i stalinowskim determinizmem mieszkańcy tego regionu bardziej lub mniej świadomie zdali sobie sprawę, że mogą uratować dla Europy zasady chrześcijańskie w znaczeniu respektowania żywej tu tradycji religijnej, zgodnie z którą prawa jednostek były mocniej postrzegane niż w zindustrializowanych krajach Zachodu ${ }^{37}$.

I znów, podobnie jak w przypadku belgijskich polityków, zamysł federacji Europy Środkowej odczytywał jako impuls do podejmowania dalszych kroków:

Dlaczego to, czego pragnę dla Środkowej Europy, nie mogłoby być również trafne dla krajów łacińskich: Włoch, Francji i Hiszpanii? $?^{38}$

W dokumentach amerykańskiego Departamentu Stanu znaleźć można z tego okresu nawet wypowiedź baskijskiego polityka Joego Antonia de Aguire, który inspirując się projektem polsko-czechosłowackim, szukał analogicznego rozwiązania problemów iberyjskich w postaci konfederacji obejmującej Katalonię, kraj Basków i Portugalię ${ }^{39}$.

Ze szczególnie ciepłym przyjęciem spotkały się koncepcje środkowoeuropejskiej federacji wśród emigracji węgierskiej, gdzie pracowano nad „planem Eckharda-Pelényiego". Odnosząc się do pomysłów fetowanych w Londynie, węgierscy opozycjoniści koncentrowali uwagę na współdziałaniu trzech ściśle ze sobą współpracujących związków federacyjnych: polsko-bałtyckiego, dunajskiego i bałkańskiego, których organizacyjna rola miała wynikać z przewagi liczebnej i historycznych zasług ${ }^{40}$. Plan ten cieszył się szczególnym poparciem demokratów skupionych wokół Mihálya Károlyiego ${ }^{41}$ i był brany pod uwagę w pracach wspomnianej już amerykańskiej Komisji Doradczej²

Optymizmu, jaki wywołały deklaracje państw środkowoeuropejskich, nie podzielali (choć wygląda to na paradoks) sygnatariusze obu dokumentów. Choć E. Beneš opublikował obszerny artykuł w „Foreign Affairs”, w którym starał się sprawić wrażenie, że porozumienia te będą stanowić ważny krok do konsolidacji całej Europy ${ }^{43}$, nie zmieniało to nastroju przygnębienia wśród uczestników negocjacji. Narastały wątpliwości co do szans realizacji tej idei, z powodu obaw wynikających ze stanowiska Moskwy. W tym kontekście dwuznaczna była wypowiedź H. Ripki, sekretarza stanu w MSZ czechosłowackiego rządu na uchodźstwie, na antenie BBC w przededniu podpisania deklaracji. Witając z zadowoleniem układy, podkreślił on doniosłą rolę Związku Radzieckiego w rozwiązaniu spraw Europy Środkowej ${ }^{44}$.

${ }^{37}$ C. Sforza, The Future: Federation in Central Europe, [w:] The Totalitarian War and After, Chicago University Press 1941, cyt. za: W. Lipgen s (red.), Documents on the History of European Integration (dalej: DHEI), Walter de Gruyter Berlin-New York 1986, t. II, s. 509.

38 Ibidem.

39 NA, RG 59 box 84 , loc. cit.

${ }^{40}$ NA, Notter File, box 55, 9 V 1942; Zob. także: T. E c k hard, The Problem of the Middle Danubian Basin, Hungarian Quarterly, Spring 1944 s. 8-12.

41 S. B or s ody, The New Central Europe, Columbia University Press, New York 1993, s. 56.

42 J. Laptos, M. Mis zt a l, op. cit., s. 205-206.

${ }^{43}$ E. B en e s, The Organization of Post-War Europe, Foreign Affairs, t. XX, January 1942, s. 238 i n.

${ }^{44}$ M. K. K a m iń s k i, Edvard Beneš kontra gen. Władysław Sikorski. Polityka władz czechosłowackich na emigracji wobec rządu polskiego na uchodźstwie 1939-1943, Wyd. Neriton, Warszawa 2005, s. 145. 
Greccy i jugosłowiańscy politycy, składający podpisy pod deklaracją, również wydawali się zaskoczeni własną odwagą i, jak się wydaje, traktowali wypracowany dokument jako rodzaj memorandum publicznie, za pośrednictwem Sikorskiego, przedstawionego Wielkiej Brytanii, poniekąd na jej życzenie ${ }^{45}$. Wiadomo obecnie, że w trakcie rozmów dotyczących szerszej konfederacji Momčilo Ninčić zwierzał się posłowi brytyjskiemu George'owi Rendelowi ze swych obaw przed reakcją Rosji na wieść o utworzeniu konfederacji ${ }^{46}$. Z kolei Tsouderos, informując Edena o rozmowach z Sikorskim, uskarżał się, że „deprecjonował" on wszelkie argumenty odnoszące się do stanowiska Moskwy ${ }^{47}$, które, jak twierdzi w swych pamiętnikach Marcel-Henri Jaspar, pozostający wówczas w bliskim kontakcie z Aleksandrem Jefremowiczem Bogomołowem, ambasadorem radzieckim przy rządach emigracyjnych, było rzeczywiście wrogie owym zamysłom ${ }^{48}$.

Najdłużej wiarę w realizację przyjętych zobowiązań zachował Sikorski. Polski premier, przekonany, że ma poparcie Anglosasów, i nieporzucający złudzeń co do zgody Stalina, usilnie zabiegał w tym czasie o zaakceptowanie udziału Litwy w przyszłej federacji. W nadziei na ziszczenie owego marzenia podtrzymywał go Retinger, zapewniając, że jego ,„przyjaciel” Stafford Cripps popiera zamysł pozostawienia w związku z Polską całej Litwy ${ }^{49}$. Przesłanek do snucia marzeń można było nieco znaleźć; wszak po rozmowach prowadzonych jesienią 1941 r. przez Raczyńskiego z posłem litewskim w Londynie oraz przez Aleksandra Ładosia z Radą Posłów Litewskich za granicą (Tauraskasem, Łozorajtisem, Klimasem i Szaulisem) w Szwajcarii ${ }^{50}$ doszło tuż po przyjęciu deklaracji polsko-czechosłowackiej (23 I 1942 r.) do podpisania wspólnej deklaracji polsko-litewskiej, nawiązującej do „odwiecznej więzi obu narodów"51.

O losach konfederacji zadecydować miało stanowisko wielkich mocarstw. Zapowiedź tego, co się mogło zdarzyć, pojawiła się w rozmowie Harry’ego Hopkinsa z Edenem po rozmowie tego ostatniego $\mathrm{z}$ ambasadorem radzieckim w Londynie. Obydwaj dyplomaci mieli wrażenie, że rząd radziecki nie był zachwycony propozycjami federacji środkowoeuropejskiej. Jak twierdził bowiem Majski, federacja obejmująca określoną liczbę małych państw mogłaby przynieść może ,pewne korzyści o charakterze ekonomicznym”, ale nie miałaby większego znaczenia z politycznego i militarnego punktu widzenia ${ }^{52}$.

Atmosferę panującą w tym czasie w Departamencie Stanu oddaje bardzo dobrze memorandum sporządzone przez jednego z wysokich urzędników Departamentu Stanu dla podsekretarza stanu Sumnera Wellesa w dniu 23 marca 1942 r., a więc dokładnie

45 Potwierdzają to dane wywiadu amerykańskiego, ale i one są skromne, jeśli chodzi o przebieg negocjacji. Zob. NA OSS RG 226, INT-14 GR, raport z 3 lutego 1942.

46 Szerzej: S. K. Pavlowitch, Momčilo Ninčić and the European Policy of the Yugoslav Government in Exile, 1941-1943, The Slavonic and East European Review, vol. 62, nr 3, s. 400-420, nr 4 (531-551) (lipiec i październik 1984).

47 Zob. A. J. Prażmows k a, Britain and Poland 1939-1943. The Betrayed Ally, Cambridge University Press 1997, s. 140-141.

48 P.-H. J a s p a r, Souvenirs sans retouches. Changement de décors, Fayard, Paris 1968, s. 61.

${ }^{49}$ L. Mitki ew ic z, op. cit., notatka z 9.03.1942 r., s. 223.

50 Szerzej na ten temat:. K. Tarka, Konfrontacja czy wspótpraca? Litwa w polityce Rządu Polskiego na uchodźstwie 1939-1945, Wydawnictwo Uniwersytetu Opolskiego, Opole 1998.

51 E. R a c zyń s k i, W sojuszniczym Londynie, Londyn 1960, s. 132-133.

${ }_{52}$ R. E. S herwood (ed.) The White House Papers of Harry L. Hopkins, Eyre \& Spottiswood, London 1949 , t. II, s. 711. 
i nieprzypadkowo w przeddzień drugiej oficjalnej wizyty polskiego premiera w Stanach Zjednoczonych.

Jego (Sikorskiego - J.Ł.) wysiłki, by w obecnej sytuacji położyć fundament pod europejską konfederację, wolną od rosyjskich wpływów, są oczywiście skazane na niepowodzenie, zwłaszcza teraz, gdy przywódcy innych rządów emigracyjnych obawiają się podejmowania jakichkolwiek działań, z obawy przed reakcją Związku Radzieckiego, a głównym celem rządu brytyjskiego jest utrzymywanie Stalina w dobrym humorze ${ }^{53}$.

W tych warunkach argumenty Sikorskiego wysuwane w czasie rozmowy z Rooseveltem i w specjalnym memoriale złożonym na ręce S. Wellesa, mające dowodzić, iż federacja środkowoeuropejska przyczyniłaby się do zapewnienia trwałego pokoju ${ }^{54}$, nie spotkały się z pozytywnym odzewem. Welles w tydzień po rozmowie z Sikorskim dokonał zresztą swoistego plagiatu metafory użytej przez swego podopiecznego do określenia polityki brytyjskiej i w liście do Biddle’a stwierdził, że zadaniem Stanów Zjednoczonych jest również „to keep Stalin in a good humor”. Równocześnie dziękował Biddle’owi za pomoc w odłożeniu ad acta (shelving) planów Sikorskiego związanych z konfederacją, dodając, iż ,teraz nie czas na lansowanie projektów dotyczących powojennych rozwiązań, które mogłyby obrażać Rosjan ${ }^{55}$ ".

Pikanterii całej sprawie dodaje przekora, na jaką się zdobył podsekretarz stanu wobec swego ambasadora, zafrapowany najwyraźniej wspomnianą metaforą:

Z drugiej jednak strony nie możemy stale stać na stanowisku, że dla podtrzymywania dobrego humoru Rosjan należy się godzić na ich projekty dotyczące powojennej Europy ${ }^{56}$.

Przekora była chyba jednak głębiej osadzona, niż by to mogło się wydawać z lektury depeszy, bowiem kilka tygodni później (9 maja 1942 r.) pod kierownictwem Sumnera Wellesa, i zapewne z jego inicjatywy ${ }^{57}$, rozpoczął działalność wielokrotnie tu wzmiankowany Komitet Doradczy przy Departamencie Stanu, zajmujący się projektem federacji środkowoeuropejskiej ${ }^{58}$.

Tak więc idea federacji środkowoeuropejskiej opuszczała z pewnym ociąganiem biura Białego Domu i kancelarie dyplomatyczne, by stać się przedmiotem teoretycznie alternatywnych rozwiązań dla amerykańskiej polityki wobec Europy Środkowej i zająć w szerokiej opinii publicznej poczesne miejsce wśród wielu innych idealistycznych wizji lepszego świata. Do malejącego grona jej entuzjastów przyłączył się nieoczekiwanie znany pisarz amerykański Eric Knight (autor Lassie wróć), który zapragnął przekonać dla tej „zachwycającej idei” swych rodaków, twierdząc, że inspiracją i paradygmatem proponowanego przez Sikorskiego związku narodów był przecież ustrój Stanów Zjedno-

${ }^{3}$ Foreign Relations of United States (FRUS) 1942, t. III. Memorandum by acting Chief of the Division of European Affairs Atherton to the Undersecretary of State (Welles), Washington, 23.03.1942.

${ }^{54}$ Ibidem, Washington 25.03.1942, notatka z rozmowy S. Wellesa z Sikorskim, s. 130.

55 Ibidem, Waszyngton, 4.04.1942, S. Welles do Biddle'a, s. 137.

56 Ibidem.

57 Zob. C. D. O'S ulliva n, Sumner Welles. Postwar Planning and the Quest for a New World Order, 1937-1943, Columbia UP, New York 2008, s. 154 i n.

${ }^{58}$ Efekty ich pracy to bogaty zbiór dokumentów zwany Notter Files, znajdujący się w U.S. National Archives, do którego wielokrotnie się odwołujemy. 
czonych. Na dowód przytoczył znamienne słowa Sikorskiego wypowiedziane na jednym z mityngów w Ameryce:

Zapraszamy do naszej federacji także Rumunię, Węgry, Austrię i Bułgarię. Dziś, co prawda, państwa te są sojusznikami państw Osi, ale po części stało się to wbrew ich woli. Wyciągamy do nich pomocną dłoń. To, czego Ameryka już dokonała w przeszłości, nasze małe państwa Europy Środkowej muszą uczynić w najbliższej przyszłości. Nie mówię, że będzie to łatwe, ale nie było łatwo także w Valley Forge ${ }^{59}$.

Nie wiadomo, które $\mathrm{z}$ tych informacji i w jakiej formie docierały do szefa polskiego rządu na emigracji, ale powoli pozbywał się złudzeń co do polityki wielkich mocarstw i swego partnera Beneša. To, czego nie mógł sobie uświadomić bezpośrednio po wizycie w Stanach, wyłożył miesiąc później w nocie do Edena, sporządzonej po zapoznaniu się z tekstem układu sojuszniczego angielsko-radzieckiego: „Układ ten, w zasadzie, grzebie przyszłość federacji środkowoeuropejskiej” ${ }^{60}$. „W zasadzie” oznaczało, że jeszcze tliły się pewne złudzenia. 4 lipca 1942 r. Beneš rozmawiał z Mołotowem w czasie jego wizyty w Londynie i wyniósł z tego spotkania przeświadczenie, że Moskwa nie jest jednak przeciwna federacji polsko-czechosłowackiej ${ }^{61}$. Pośrednim potwierdzeniem tej opinii było zatwierdzenie tego samego dnia przez rząd czechosłowacki rezolucji (rząd polski przyjął ją dzień później), w której obie strony uznawały, że pierwszorzędnym celem ich państw po zakończeniu wojny będzie utworzenie konfederacji, mającej

(...) stanowić podstawę regionalnej organizacji tej części Europy, z którą związane są żywotne interesy obu krajów ${ }^{62}$.

Kilka dni później wartość tej deklaracji została zredukowana do zera. 15 lipca 1942 r. Aleksander Bogomołow podczas wizyty, którą złożył Janowi Masarykowi, oznajmił bowiem, iż jest upoważniony do stwierdzenia, że „rząd radziecki jest oficjalnie przeciwny jakimkolwiek federacyjnym poczynaniom w obecnej dobie", i dodał, że dotyczy to także konfederacji polsko-czechosłowackiej ${ }^{63}$. Moskwa nie ogłosiła jednak oficjalnego stanowiska, pozwalając karmić się złudzeniami jeszcze przez kilka miesięcy.

Mając do czynienia z coraz liczniejszymi przejawami empatii ze strony mocarstw anglosaskich i korzystając z sytuacji na froncie, rosyjskie władze uznały, że nadszedł czas, by publicznie zaatakować projekt federacji środkowoeuropejskiej. Głównego uderzenia dokonano za pośrednictwem prasy, a dokładniej jednego jej organu „Wojna i Raboczij Kłass", wydawanego, ku wygodzie zachodnich ambasad, również w wersji angielskiej. Pierwszy artykuł na ten temat, jaki został dostrzeżony przez dyplomatów, ukazał się 15 lipca 1943 r. i nosił wymowny tytuł Co kryje się za projektem federacji środkowoeuropejskiej? R. van Kerchove d'Hallebast, ambasador Belgii w ZSRR, który go analizo-

59 E. Knight, Will Peace bring a United States of Eastern Europe?, The Saturday Evening Post, 8.08.1942 (zał. do raportu z 15.08.1942, NA OSS RG 226, INT-21 Po. 66). Valley Forge, dolina będąca symbolem oporu i zwycięstwa armii Waszyngtona w wojnie z 1777/1778 r.

${ }^{60}$ FRUS 1942, t. III, Londyn, 24.04.1942, Biddle do Sekretarza Stanu. Streszczenie noty Sikorskiego do Edena, s. 141.

${ }^{61}$ Cyt. za: S. B or s ody, op. cit., s. 68.

${ }^{62}$ M. K. Ka miń s k i, Edvard Beneš..., s. 187.

${ }^{63}$ Ibidem, rozdział III i IV. 
wał w swym raporcie, dochodził do wniosku, że ostrze ataku zostało skierowane przede wszystkim w polskich polityków. Anonimowy autor zarzucał im mieszanie się do spraw wewnętrznych innych państw i przekonywał, że projekt federacji miał na celu zaspokojenie polskich ambicji terytorialnych, a w dodatku był zabarwiony antysemityzmem, bo zamierzał postawić tamę powrotowi do Polski Żydów, rozproszonych na wschodzie i na zachodzie. Belgijski dyplomata nie dał się zwieść tej wykładni i był przekonany, że „,rosyjskie weto dotyczy wszystkich koncepcji federacyjnych w Europie” i pośrednio adresowane jest także do Anglików. Nie umknęło mu bowiem zawarte w artykule stwierdzenie, iż

uczciwi zwolennicy układu sojuszniczego (brytyjsko-radzieckiego - J.Ł.) nie mogą stawać w obronie planów powojennych wrogich wobec Związku Radzieckiego i Wielkiej Brytanii, bądź jednego z tych państw ${ }^{64}$.

Kolejny artykuł odrzucający zamysł federacji środkowoeuropejskiej, dostrzeżony w „Biuletynie Prasowym” Ambasady ZSRR w Waszyngtonie z 24 sierpnia 1943 r., był także przedrukiem $\mathrm{z}$ nieocenionego periodyku ${ }^{65}$. Tym razem niejaki I. Malinin dowodził, że elementy faszystowskie snują fantastyczne plany skierowane przeciwko Związkowi Radzieckiemu, zmierzające do wykluczenia go z udziału w powojennych decyzjach. Autor piętnował już bez ogródek wszelkie proponowane federacje, konfederacje i bloki, określając je mianem ,antydemokratycznych i reakcyjnych”, ale ze szczególną zajadłością zwalczał projekt związku środkowoeuropejskiego z udziałem Polski ${ }^{66}$. Dwa dni później agencja prasowa Associated Press opublikowała depeszę, informującą, że Moskwa pragnie zachować wiodącą rolę (leading role) w powojennej organizacji świata i patrzy niechętnie na Stany Zjednoczone Europy przybierające postać ,,various federations”.

W wigilię rocznicy agresji radzieckiej na Polskę kolejny dziennikarz widmo K. Demidow - przystąpił na łamach pisma „Wojna i Raboczij Kłass”67 do ataku na Plan Sikorskiego, uciekając się do swoistej recenzji pracy T. Lutosławskiego, wydanej pod pseudonimem G. Harrison i Peter Jordan i zatytułowanej Central Union ${ }^{68}$. Prezentowana w tej książce koncepcja związku zgrupowanych wokół Polski państw, leżących między trzema morzami, w której idea jagiellońska odsłaniała się w postaci niemal krystalicznej, stała się łatwym łupem ${ }^{69}$. Demidow uważał ów związek za kamuflaż

${ }^{64}$ DDB t. I, dok. 159, Kerchove d'Hallebast do MSZ, Kujbyszew 2 VIII 1943. Streszczenie tego samego artykułu przesłał także Roger Garreau, przedstawiciel Wolnej Francji w Kujbyszewie do Francuskiego Komitetu Wyzwolenia Narodowego w Algierze. Zob. T. Wy r w a, L’idée européenne dans la Résistance à travers la presse clandestine en France et en Pologne 1933-1945, Nouvelles Editions Latines, Paris1987, s. 117-118.

${ }^{65}$ Zob. F. Gros s, Federacje i konfederacje europejskie. Rodowód i wizje, Instytut Studiów Politycznych PAN, Warszawa 1994, s. 55.

${ }^{66}$ Times Picayne, 26.08.1943, cyt. za raportem belgijskiego konsula gen. w Nowym Orleanie, A. Rennesa z 27.08.1943, Archives du Ministère des Affaires Etrangères (Bruksela), t. 11775. Artykuł ten był znany również F. Grossowi, op. cit., s. 80 .

${ }^{67}$ K. Demidow, Panowie polscy w Bedlam, Wojna i Raboczij Kłass, 15 IX 1943, za thum. na j. franc. AMAE(b), t. 17, 775 .

68 Praca ta miała dwa wydania. Pierwsze, o którym tu mowa, ukazało się w Londynie w 1943 r., drugie pod nieco zmienionym tytułem (Central Union of Europe) opublikowane zostało w Nowym Jorku w 1944 r.

${ }^{69}$ Dostrzegał to także amerykański agent OSS - Ph. Horton, wskazując na mapkę połączonej Polski i Litwy jako „keystone of the arch” owego Związku Środkowoeuropejskiego. NA OSS RG 226, Eu-306. raport z 8.01.1944. 
(...) bardzo starej i fantastycznej Polski od morza do morza, dla realizacji której proponuje się aneksję Estonii, Litwy i Łotwy, nie mówiąc o części Ukrainy i Białorusi.

Nie ukrywając odrazy do owej, ,imperialistycznej manii, odwiecznej choroby polskich szowinistów", Demidow proponował leczenie ogarniętych nią polityków w Bedlam (angielskim odpowiedniku Tworek) za pomocą sprawdzonych środków - zimnych pryszniców. Zimny prysznic w metaforycznej postaci miał, jak należy wnosić, ochłodzić także umysły zachodnich zwolenników federacji w przededniu konferencji moskiewskiej ${ }^{70}$.

Te ataki nie mogły pozostać bez echa. Ich charakterystycznym przełożeniem stało się wystąpienie F. C. Cocksa 21 września 1943 r. w Izbie Gmin, który przypomniał, iż

Jakiś czas temu dały się słyszeć głosy reakcyjnych sił z Polską na czele, proponujących federację, która miałaby tworzyć barierę między Rosją Radziecką a resztą Europy. W konkluzji swego wywodu stwierdzał: Miło byłoby usłyszeć, że Anglia i Ameryka nie popierają żadnego $\mathrm{z}$ tego rodzaju planów ${ }^{71}$.

Ostatecznie złudzenia co do stanowiska ZSRR miały się rozwiać na konferencji ministrów spraw zagranicznych w Moskwie (19-30 X 1943 r). Kiedy Eden, zgodnie z posiadanymi instrukcjami, usiłował włączyć do programu spotkań zagadnienie federacji środkowoeuropejskiej, spotkał się ze zdecydowanym ,nie” ze strony Mołotowa, mającego tym razem po swej stronie amerykańskiego sekretarza stanu Cordella Hulla. Czytając relacje z przebiegu konferencji, można odnieść wrażenie, że Mołotow był wręcz zdumiony tupetem swego brytyjskiego rozmówcy, zdającego się lekceważyć akcję prasową.

Niestrudzony w swej dyfamacyjnej akcji periodyk „,Wojna i Raboczij Kłass” przystąpił znów do ataku w dniu 1 listopada 1943 r., z okazji zakończenia konferencji moskiewskiej. Tym razem artykuł został dostrzeżony przez Williama A. Harrimana, który w raporcie dla Departamentu Stanu przytaczał następujący fragment:

Jest rzeczą oczywistą, że pod pozorem federacji próbuje się ożywić znaną politykę „,kordonu sanitarnego" skierowanego przeciwko Związkowi Radzieckiemu ${ }^{72}$.

Dyplomata amerykański donosił w kolejnych depeszach, że oburzenie wobec pomysłów „,federacji Europy Wschodniej” manifestowały bluntly także „Izwiestia”. Chodziło o artykuł z 18 listopada 1943 r., polemizujący z opiniami, jakie pojawiły się w ,,The New Statesman” z 10 listopada i w ,The Economist” z 11 listopada 1943 r. na temat federacji małych państw w powojennej Europie. Tygodniki te nieopatrznie wysnuły wniosek z deklaracji konferencji moskiewskiej na temat Austrii, że Rosja nie jest przeciwna łączeniu się państw Europy Środkowowschodniej. „Izwiestia” prostowały te interpretacje, będące „wytworem fantazji autorów”, podkreślając, że należy brać pod uwagę konkretną sytuację, a nie abstrakcyjne pomysły:

${ }^{70}$ H. M i c h e 1, La seconde guerre mondiale, t. II, PUF, Paris 1969, s. 84.

71 Cyt. za: G. Kacew ic z, Great Britain, The Soviet Union and the Polish Government in Exile 1939-1945, Martins Nijhoft Publishers, Hague-Boston-London 1979, s. 149.

72 Cyt. za: FRUS 1943, t. III, przypis 18, s. 592. W relacji New York Timesa z konferencji w Moskwie znalazło się podobne stwierdzenie: ,Rosja jest przeciwna kordonowi sanitarnemu tworzonemu pod maską środkowoeuropejskiej federacji zdominowanej przez Polaków” (Ibidem, s. 607). 
Małe państwa w płynnym okresie powojennym będą miały czas na dostosowanie się do nowej sytuacji powstałej w wyniku wojny. Należy też stwierdzić, że niektóre projekty federacyjne zalatują nieprzyjemnym zapaszkiem stęchlizny, towarzyszącym od dawna już zbankrutowanej, wrogiej wobec ZSRR polityki.

Ambasador belgijski w Moskwie, który przekazywał swe wrażenia z lektury tego samego artykułu, dostrzegł pojawienie się argumentu szczególnego (z którego nie czyniono dotychczas użytku), a mianowicie zarzutu włączania do federacji środkowoeuropejskiej, na równi z pozostałymi jej członkami, państw satelickich III Rzeszy, współodpowiedzialnych za zbrodnie hitlerowskie ${ }^{73}$.

Trudno ocenić, jaki wpływ na opinię brytyjską wywarły owe ataki rosyjskie, ale musiały pozostawić wyraźny ślad, skoro rok później (1 X 1944) „Manchester Gauardian” pisał, że „Polska powinna porzucić marzenia o wschodnim imperium ${ }^{74}$ ".

W tym też czasie, i nie bez związku z całą akcją, Stalin powołał trzy komisje badawcze pod przewodnictwem Iwana Majskiego, Maksima Litwinowa i Klimenta Woroszyłowa, mające wypracować aktualne cele, o których osiągnięcie będzie zabiegać państwo radzieckie w wyniku wygranej wojny. Ich konkluzje, jak wiadomo z otwartych obecnie archiwów, zmierzały do koncepcji sfery wpływów ${ }^{75}$.

Idea federacji środkowoeuropejskiej nie przepadła wraz z utratą poparcia ze strony wielkich mocarstw i nie udało się jej schować pod wycieraczką konferencji jałtańskiej. Pozostali jej wierni federaliści wszelkiej maści, a przede wszystkim środowiska emigracyjne, dla których stawała się ponownie marzeniem, przeistaczającym się powoli w narzędzie walki z komunizmem. Pojawiała się także w pomysłach licznych organizacji szukających alternatywnych rozwiązań powojennych problemów. Do najbardziej znanych należała niewątpliwie wspomniana wyżej Rada Planowania dla Europy Środkowej i Wschodniej (Central European Planning Board $\mathrm{CEPB}^{76}$ ), którą kierował Sava Kosanović, korzystając ze wsparcia bardzo zaangażowanego sekretarza generalnego Feliksa Grossa ${ }^{77}$.

W interesującym nas okresie CEPB wystąpiła z kolejną inicjatywą, jaką było zwołanie 7 kwietnia 1943 r. konferencji mającej na celu przygotowanie podstaw reformy oświaty w powojennej Europie Środkowej ${ }^{78}$. Prace przygotowawcze prowadzono we współpracy z New York University i rządowymi organizacjami oświatowymi. Konferencja wypracowała rezolucję dotyczącą wzmożenia współpracy uniwersytetów amerykańskich z europejskimi i cenną, choć zapomnianą „Kartę demokratycznego nauczania”. Ten obszar działań otwierał szerokie perspektywy. W kwietniu 1943 r. powstał nawet Institue on Educational Reconstruction in Central and Eastern Europe, a wokół CEPB zgrupowało się

${ }^{73}$ FRUS 1943, t. III, p. 600-604, Moskwa, 22 X 1943, Harriman do Sekretarza Stanu; DDB, t. I, dok. 100, Moskwa, 20 XI 1943, D.R. van de Kerchove d'Hallebast do P.-H. Spaaka.

74 N.N., Poland, Manchester Guardian, 1.10.1944.

75 V. O. Ple ch a tn ov, The Big Three after World War II: New Documents on Soviet Thinking about Postwar Relations with the United States and Great Britain, Working Papers, nr 13, Cold War International History Project, Washington DC, 1995, s. 31.

${ }_{76}$ W skład CEEPB wchodzili ponadto: J. Masaryk, J. Nečas, A. Dimiatrios, E. Tsouderos, J. Stańczyk.

77 Zob. wywiad z F. Grossem na ten temat, przeprowadzony przez J. B atora i S. Łukasiewicza, Najgorsze jest okrucieństwo, Gazeta Wyborcza, 2-3.09.2000.

78 Polish Institute of Sciences and Arts (dalej: PIASA), Materiały Feliksa Grossa, Box 9. 
wiele organizacji o podobnych aspiracjach ${ }^{79}$. Wkrótce jednak przyszło załamanie. Wycofanie się rządu czechosłowackiego z prac nad konfederacją, w związku z przygotowaniami do zawarcia układu z Rosją, spowodowało także spadek zainteresowania działaniami w ramach CEPB. Jesienią tegoż roku z prac w organizacji zrezygnowali również Grecy, a następnie Jugosłowianie. Bezpośrednim powodem było wykluczenie z rządów emigracyjnych Aristidesa Dimitratosa i Savy Kosanovicia ${ }^{80}$, ale de facto zaważyła wspomniana wyżej utraty wiary w rozwiązania o charakterze demokratycznym na Bałkanach ${ }^{81}$.

Koncepcje federalistyczne w tym czasie ożywały, niejako na przekór rzeczywistości, $\mathrm{w}$ organizacjach prointegracyjnych powstających w środowiskach brytyjskiej lewicy. $\mathrm{Na}$ uwagę zasługuje organizacja związana z Fabian Society, opowiadająca się za federalizacją środkowej części Europy, a mianowicie Klub Naddunajski. Poza Anglikami należeli doń emigracyjni lewicowi przedstawiciele Albanii, Austrii, Bułgarii, Czechosłowacji, Grecji, Polski, Rumunii, Węgier i Jugosławii ${ }^{82}$. W październiku 1943 r. Klub opublikował w Londynie projekt zatytułowany Środkowo- i południowo-wschodnia Unia Europejska. Znalazły się w nim odniesienia do Karty Atlantyckiej oraz układu angielsko-radzieckiego, wspierające tezę o potrzebie dobrych stosunków takiej Unii ze wschodnim sąsiadem i ustanowienia demokratycznych rządów w poszczególnych państwach związkowych. Pominięcie w projekcie państw bałtyckich było czytelnym ukłonem w stronę Związku Radzieckiego.

Pewną ucieczką od rzeczywistości, a zarazem alternatywą dla polityki stref wpływów, był powrót do dyskusji nad ideą integracji w wymiarze kontynentalnym. Godne uwagi są zwłaszcza działania Richarda Coudenhove-Kalergiego, korzystającego spokojnie przez lata wojny z synekury, jaką było stanowisko wykładowcy na Uniwersytecie Nowojorskim. $\mathrm{W}$ interesującym nas okresie zaczął on wychodzić poza opłotki swego seminarium na temat Paneuropy i zwołał, kadłubowy siłą rzeczy, kongres paneuropejski w Nowym Jorku, który 25 marca 1944 r. przyjął Projekt Konstytucji dla Stanów Zjednoczonych Europy ${ }^{83}$. Autor tego projektu pozostał wierny dawnej wizji Paneuropy, w której nie znajdował miejsca dla Rosji ze względu na jej ustrój daleki od demokracji.

Powrót na scenę ojca Paneuropy nie mógł pozostać niezauważony. Szczególną czujnością wykazał się i tym razem periodyk radziecki „Wojna i Raboczij Kłass” z artykułem zatytułowanym $O$ kilku problemach pokoju i bezpieczeństwa powojennego. Anonimowy autor, jak głosił podtytuł, zapragnął podzielić się swymi ,impresjami z lektury prasy zagranicznej”. Odkrywał przy tym z oburzeniem, że w pewnych środowiskach wyciąga się koncepcje Coudenhove-Kalergiego przybierające postać Projektu Konstytucji dla Stanów Zjednoczonych Europy, by sugerować wprowadzenie pełnej unii celnej na terenie Europy. Dostrzegał nadto, wielce zdumiony, że publicyści angielscy tak prestiżowych dzienników,

79 Szerzej L.L. B a r r e11, op. cit., s. 107-108.

${ }^{80}$ Za: S. Łu k a s i e w i c z, Trzecia Europa. Polska myśl federalistyczna w Stanach Zjednoczonych 1940-1971, IPN, Warszawa-Lublin 2010, s. 65.

${ }^{81} \mathrm{O}$ wpływie zbliżenia rosyjsko-czechosłowackiego na nastroje w Stanach w innych środowiskach zob. także I. S t a n c i u, Romania and American Planning on a Federation in East-Central Europe during the Second World War Years, History of European Ideas, v. 20, nr 1-3, January 1995, s. 641-645.

${ }^{82}$ Na czele Klubu stał w tym czasie Philips Price, a należeli doń m.in.: Victor E. Budenau, Adam Ciołkosz, Milan Gavrilović, Jan Kuncewicz, František Littna.

${ }^{83}$ Tekst projektu zob.: A. J. Zurcher, The Struggle to Unite Europe 1940-1958, New York 1958, s. 213-223. Dostępny także na stronie: http:// www.cvce.eu /projet-constitution-etats-unis-europe-new-york-1944. 
jak „The Spectator” czy „The Economist” opowiadali się za europejską unią gospodarczą i w dodatku widzieli w niej sposób na powstrzymanie ekonomicznej ofensywy Niemiec czy nawet agresji. Radziecki publicysta nie miał też wątpliwości, co do inspiratorów owych projektów. To byli „reakcyjni politycy”, dawni zwolennicy appeasementu wobec Hitlera, w rodzaju Raczyńskiego czy niedawno zmarłego Hodžy, wspierani przez „monachijskie elementy w Wielkiej Brytanii" ${ }^{\prime 4}$.

Było niewątpliwie sporo tupetu albo naiwności w propagowaniu projektów federacji w czasie, gdy wszyscy poddawali się ,żelaznej” woli Stalina odnośnie do ,jego” strefy. Coudenhove-Kalergi brnął jednak dalej, ogłaszając w „New York Times” z 15 marca 1945 r. Deklarację o europejskiej współzależności ${ }^{85}$. Sygnatariusze tej deklaracji zwracali się do Prezydenta i Kongresu Stanów Zjednoczonych o pomoc w utworzenia Konfederacji Europejskiej w momencie zakończenia wojny i równocześnie ostrzegali przed konsekwencjami aktualnej polityki, wyrażając przekonanie, że:

rozbiór naszego kontynentu lub jego podział na strefy wpływów doprowadzi w przyszłości do trzeciej wojny światowej ${ }^{86}$.

Coudenhove-Kalergi dopisywał zatem pointę do przedstawianych wyżej inicjatyw i przedsięwzięć, uzmysławiając szerokiej opinii, że projekty federacyjne stanowią formę ostrzeżenia przed konsekwencjami tego, co F. Gross określił mianem ,źle pojmowanego realizmu politycznego”, wyrażającego się w „niebezpiecznej teorii strefy wpływów”, niebędącej niczym innym jak ,reakcyjnym planem zorganizowania Europy na zasadzie panowania wielkich mocarstw" ${ }^{87}$. Koncepcje regionalnego związku środkowoeuropejskiego w nowej sytuacji stawały się jednym z drogowskazów dla emigracji środkowoeuropejskiej w jej walce o odzyskanie niepodległości.

\section{Bibliografia:}

Archiwa:

Archives Historiques de l'Union Européenne en Florence (AHUE)

Archives du Ministère des Affaires Etrangères (belges) [AMAE(b)]

National Archives of the United States, Washington D.C. (NA)

- Foreign Nationalities Branch Files 1942-1945

Polski Instytut Naukowy w Ameryce (PIN)

- Kolekcja Feliksa Grossa.

${ }^{84}$ N. D mitriej e w, O kilku problemach pokoju i bezpieczeństwa po zakończeniu wojny, Wojna i Walka Klasowa, nr 15, 1 VIII 1944 [thumaczenie za raportem belgijskiego ambasadora - AMAE(b), t. 11591.

${ }^{85}$ Tekst w j. polskim: F. Gro s s, op. cit., s. 83-85. Wśród 15 osobistości europejskich, które złożyły swój podpis, odnajdujemy Nellosa Cannellopoulosa, parlamentarzystę greckiego, Wacława Lednickiego, F. Grossa, Miloye M. Skoticia, b. redaktora Prawdy wydawanej w Belgradzie, jak też Franza Werfela, czesko-austriackiego pisarza.

${ }^{86}$ Wagę tej konferencji podkreśla także ambasador Francji w Londynie w raporcie z 17 marca 1945 i przekazuje centrali tekst deklaracji w j. angielskim. AMAE(f), Série: Europe 1944-1960, Généralités, v. 6, k. 2-4.

${ }^{87}$ F. Gros s, Powojenna Europa, tekst za: Archives Historiques Européennes, dossier W. Lipgensa, t. 127, k. $172-178$. 
Pamiętniki:

Hodza M., Federation in Central Europe: Reflexions and Remniscences, Jarrolds Publishers Limited, London 1942.

Mitkiewicz L., Z generałem Sikorskim na obczyźnie, Biblioteka Kultury, t. 157, Paryż 1968.

Raczyński E., W sojuszniczym Londynie, Londyn 1960.

Spaak P.-H., Combats inachevés, t. I, Paris 1968.

Beneš V., The Mission of Small Nations, Chicago 1941.

Opracowania:

Drąg-Korga Iwona, Polska Walczy! Działalność propagandowa rządu RP na uchodźstwie wobec społeczeństwa amerykańskiego 1939-1945, Instytut Józefa Piłsudskiego w Warszawie, Bełchatów 2011.

Gross F., Federacje i konfederacje europejskie. Rodowód $i$ wizje, INP PAN, Warszawa 1994.

Gross F., Crossroads of two Continents. A Democratic Federation of East-Central Europe, Columbia University Press, New York 1945.

Gross F., Russian political emigration of 1948, „Journal of Central European Affairs”, t. 9, lipiec 1949, s. 150-158.

Hanc J., From Polish-Czechoslovak Collaboration to Eastern Organization, „New Europe”, czerwiec 1941.

Kacewicz G., Great Britain, The Soviet Union and the Polish Government in Exile 1939-1945, Martins Nijhoft Publishers, Hague-Boston-London 1979.

Kamiński M. K., Edvard Beneš kontra gen. Władysław Sikorski. Polityka władz czechosłowackich na emigracji wobec rządu polskiego na uchodźstwie 1939-1945, Warszawa 2005.

Kisielewski T., Federacja środkowoeuropejska. Pertraktacje polsko-czechosłowackie 1939-1943, Ludowa Spółdzielnia Wydawnicza, Warszawa 1991.

Komarnicki T., Próby stworzenia związu polsko-czechosłowackiego w okresie II wojny światowej, „Sprawy Międzynarodowe”, Londyn, cz. I nr 2-3/1947, cz. II nr 1/1948.

Łaptos J., Misztal M. (red.), American Debates on Central European Union, 1942-1944. Documents of the American State Department, Presses Internationales Universitaires, Peter Lang (seria Euroclio), Bruxelles-Berlin-Frankfurt-New York-Oxford-Wien 2002.

Muhlstein A., The United States of Central Europe, „New Europe”, luty 1941.

O'Sullivan C. D., Sumner Welles, Postwar Planning, and the Quest for a New World Order, 1937-1943, Columbia UP, New York 2008. Praca dostępna on line: www.gutenberg-e.org/osc01/ frames/fosc07.html.

Prażmowska A. J., Britain and Poland 1939-1943. The Betrayed Ally, Cambridge University Press, 1997.

Znamierowska-Rakk E., Projekty unifikacji państw bałkańskich w latach II wojny światowej, „Dzieje Najnowsze" 2001/3, s. 85-97.

Zurcher A. J., The Struggle to Unite Europe 1940-1958, New York 1958.

Józef Łaptos

\section{Scope and forms of cooperation of Central European politicians in exile during the Second World War}

Summary

All the states of German-occupied Europe had their governments in exile during the Second World War. The main goal of the Central European states was to regain independence, but not to return to status quo ante, as all of them, with the laudable exception of Czechoslovakia, were auto- 
cratic before 1939. Acquiring allies required convicting them about the willingness to establish the democratic rule. One of the main arguments was the vision of Central European federation. The federation was not only a synonym of democracy, but also an opportunity to strengthen the entire area. Sikorski's government was particularly active in this field, acquiring Western allies for its plans, but did not manage to convince Stalin with their help.

Key words: Central European federation, governments in exile policy, Sikorski's plan, Polish cause during the Second World War. 